\title{
Awareness of Preventive Measures of Cardiovascular Diseases and Heart Attack Warning Symptoms: Gender-based Differences
}

\author{
Samah Saad Salem ${ }^{1}$; Hind Al Ghadeer ${ }^{2}$; Faten Albattah ${ }^{3}$; Wijdan Alanazi ${ }^{3}$ Hadeel Alanazi ${ }^{3} \&$ Naglaa Youssef $^{4}$ \\ ${ }^{1 .}$ Lecturer, Medical-Surgical Nursing Department, Faculty of Nursing, Cairo University, Cairo, Egypt. \\ Assistant professor, College of Nursing, King Saud bin Abdulaziz University for Health Sciences, Riyadh, Saudi \\ Arabia. King Abdullah International Medical Research Center, Riyadh, Saudi Arabia. \\ 2. Assistant professor, Allergyology \& Immunology, internal medicine department, King Abdulaziz medical city- \\ Riyadh, ministry of national guard health affairs, Riyadh, Saudi Arabia. King Abdullah International Medical \\ Research Center, Riyadh, Saudi Arabia. \\ 3. Nursing student, College of Nursing, King Saud bin Abdulaziz University for Health Sciences, Riyadh, Saudi \\ Arabia. King Abdullah International Medical Research Center, Riyadh, Saudi Arabia. \\ 4. Assistant professor, Medical-Surgical Nursing Department, Faculty of Nursing, Cairo University, Cairo, Egypt. \\ Assistant professor, Medical-Surgical Nursing Department, College of Nursing, Princess Nourah bint \\ Abdulrahman University, Riyadh, Saudi Arabia.
}

\begin{abstract}
Background: Cardiovascular diseases, mainly ischemic heart disease, is the first cause of mortality in Saudi Arabia (SA). Although cardiovascular diseases (CVDs) prevalence is usually lower in women than in men, women have a higher mortality rate and a worse prognosis than men. Aim: This study aims to identify the level of awareness of CVDs preventive measures and heart attack warning symptoms among the male and female Saudi population. Subjects and methods: A comparative cross-sectional study was conducted in the current study among 400 adults from Riyadh using a self-completed questionnaire. Results: Men and women had the same level of awareness about preventive measures for CVDs ( $p>0.05)$. Females had a higher awareness level than males about symptoms of chest pain (chi-square $=8.247$, at $\mathrm{p}=.005$ ) and weakness or fatigue (chi-square $=11.933$, at $\mathrm{p}=.001$ ), but their awareness level regarding other symptoms was similar. Conclusion: the study respondents had a suboptimal awareness about CVDs preventive measures and warning symptoms of heart attacks. Recommendation: Evidence-based educational intervention is required to enhance the population's knowledge and strengthen their positive attitude towards adopting a healthy lifestyle.
\end{abstract}

\section{Keywords: Awareness, Cardiovascular Diseases, Heart Attack \& Gender-based}

\section{Introduction}

Globally, cardiovascular diseases (CVDs) account for the most non-communicable diseases (NCDs) mortalities (World Health Organization, 2017). Although CVDs are preventable and treatable, they are still one of the leading causes of death and disability worldwide. In 2016, CVDs caused 17.9 million deaths, representing more than a quarter of all global deaths; $85 \%$ were due to heart attack and stroke (WHO, 2017). Although efforts are being made in developed countries to reduce the incidence of CVDs, the numbers are still increasing. Moreover, the number of deaths is expected to rise to 23.6 million or more by 2030 worldwide (Benjamin et al., 2019).

Cardiovascular diseases, mainly ischemic heart disease, is the first cause of mortality in Saudi Arabia (Centers for Disease Control and Prevention [CDC], 2018); 36\% of deaths and 13\% of disabilities were caused by CVDs (Saudi Ministry of Health, 2013). This number is estimated to increase twofold by 2035 (Gagnon, 2021). Heart diseases create enormous health and economic burdens globally (Virani et al., 2020). The economic burden of CVDs in SA has been expected to increase from US\$3.5 billion in 2016 to US\$9.8 billion by 2035 (Gagnon, 2021).

Although the prevalence of CVDs is usually lower in women than in men, women have a higher mortality rate and a worse prognosis than men (Zhou \& Bei, 2020). There were almost 400,000 deaths in women in the USA due to CVDs and stroke, including a minor variation due to ethnicity (Benjamin et al., 2018; Coke \& Hayman, 2021). The most predominant factors of differences in the prevalence of CVDs among women and men are attributed to cardiac structure and function, sex hormones, sociopsychological characters, nutrition, and lifestyle (Blïher, 2019; Zhou \& Bei, 2020).

\section{Significance of the study}

The prevalence of CVD risks is high among Saudi women, as around a quarter to a third suffers from diabetes, hypertension, and hypercholesterolemia. More than half are overweight, obese, and physically 
inactive (Alshaikh et al., 2016). Gender differences must be taken seriously during the assessment of prevalence and risk factors for CVDs. It is of great importance to determine the appropriate ways of prevention, diagnosis, treatment, and management of CVDs (Coke \& Hayman, 2021; Gao et al., 2019). Awareness of CVD risks and preventive measures among Saudi women compared to men has not been significantly explained in the literature. The current study findings will enhance the insight of healthcare professionals, especially cardiovascular nurses, community health nurses, and healthcare policymakers, about the Saudi population's awareness of CVDs risk factors and preventive measures based on gender.

\section{Aim of the study}

The current study aims to identify the level of awareness of cardiovascular diseases (CVDs) preventive measures and heart attack warning symptoms among the male and female Saudi population.

\section{Research questions}

Three research questions were stated to achieve the aim of this study:

1. What is the level of awareness among males and females regarding CVDs risks preventive measures?

2.Is there a difference between the males and females awareness regarding heart attack warning symptoms?

3. What factors are significantly related to the level of awareness about heart attack warning symptoms and CVDs preventive measures?

\section{Material and Methods \\ Design and setting}

A cross-sectional comparative survey was conducted over a month to recruit eligible people (December 15, 2019 , to January 15,2020 ). The study sample recruited from public places in Riyadh, such as malls, parks, waiting areas in hospitals, and libraries.

\section{Population and sample size}

A convenience sample of adults aged $\geq 18$ years old, living in Riyadh city, and accepted to participate in the study was recruited. Healthcare workers were excluded from the study to avoid selection bias since they are more likely to have a higher medical knowledge level than the general population. The www.raosoft.com website was used to calculate the sample size with a 5\% margin of error. A 95\% confidence level was accepted for the total population of 9,600,000 in Riyadh city. Hence, the minimum number for the required sample was 385 , which was increased to 400 to avoid any missed data or dropout.

\section{Instruments}

The researchers developed a three-section questionnaire after an extensive review of relevant literature (Alotaibi et al., 2018; Aminde et al., 2017; Awad \& Al-Nafisi, 2014; Mujamammi et al., 2020).

First section: Background Data Sheet

It consisted of 13 items related to sociodemographic and biomedical data of the study sample.

Second section: Warning Symptoms Questionnaire It consisted of six common warning symptoms of a heart attack to assess the awareness level; each item had three responses (0. no, 1. not sure, 2. Yes). Each correct answer was given a point to obtain a total score of 12. A score from 0 to 4 indicates an insufficient level of knowledge, from 5 to 8 indicates a moderate level of knowledge, while 9 to 12 indicates a good level of knowledge.

Third section: Preventive Measures of CVDs Questionnaire

It included nine items to assess the awareness level of the respondents about CVDs preventive measures. However, it did not assess their actual practices since this might cause a response bias. The response scale ranged from strongly agree $(=5)$ to strongly disagree $(=1)$, which gave a total score from 9 to 45 . A score from 9 to 21 indicates a low level of awareness, from 22 to 33 indicates a moderate level of awareness, while 34 to 45 indicates a high level of awareness.

Validity and Reliability of the Study Instruments;

Three medical-surgical nursing and community health nursing experts reviewed the study tools before it was used. The tools were evaluated for clarity, relevancy, applicability, comprehensiveness, and understanding. Changes have been made in response to their suggestions to make it readable and understandable to the respondents. The reliability of the second and third sections of the questionnaire was assessed using Cronbach Alpha, which was 0.70 and 0.64, respectively.

\section{Ethical considerations}

The study was approved (SP19/536/R) by the Research Unit - College of Nursing, King Saud bin Abdulaziz University for Health Sciences, and Institutional Review Board (IRB) in King Abdullah International Medical Research Canter (KAIMRC), National Guard Health Affairs, Riyadh, Saudi Arabia. The respondents gave informed consent after explaining the aim of the study. The researchers emphasized the right of the participant to withdraw from the study at any time. Privacy and confidentiality were maintained, and no identifier data were collected.

Pilot study

A pilot study was conducted on $10 \%$ of the study sample (40 respondents) to test the clarity and 
feasibility of the developed instruments. Also, it provided an estimation of the time needed to fill out the tools. Minor modifications were done based on the findings obtained from the pilot study. The sample in the pilot study was not included in the study sample and compensated with the same number of males and females.

\section{Data collection method}

Data collection was conducted over a month to recruit eligible people (December 15, 2019, to January 15, 2020) for three days a week. The researchers recruited the participants from public places in Riyadh, such as malls, parks, waiting areas in hospitals, and libraries after ensuring their voluntary participation. The researchers introduced themselves to the eligible participants and briefly explained the aim and methodology of the study then they started to distribute the questionnaire, this step took about 30 minutes for each participant to fill it.

\section{Statical analysis}

The Statistical Package for the Social Sciences (SPSS) version 26 (IBM SPSS Statistics, New York, USA) was used to analyze the data. A descriptive analysis was used to present a statistical summary for the sociodemographic data, medical health history variables, economic status, stress level, awareness of CVDs preventive measures, and heart attack symptoms. A Student T-Test and ANOVA and A Chi-Square were used to identify factors associated with awareness and comparison of sociodemographic data between males and females. All tests were carried out at a p-value of 0.05 .

\section{Results}

Table (1): Sociodemographic characteristics of the respondents, $n=400$

\begin{tabular}{|c|c|c|c|c|c|}
\hline \multirow{2}{*}{\multicolumn{2}{|c|}{ Sociodemographic data }} & $\begin{array}{l}\text { Entire } \\
\text { sample }\end{array}$ & $\begin{array}{c}\text { Male } \\
\mathbf{N}=\mathbf{1 7 0}\end{array}$ & $\begin{array}{l}\text { Female } \\
N=230\end{array}$ & \multirow{2}{*}{$\begin{array}{l}\text { Chi-square } \\
\text { (p-value) }\end{array}$} \\
\hline & & $\mathrm{N}(\%)$ & \multicolumn{2}{|c|}{$\mathbf{N}(\%)$} & \\
\hline Age & $\begin{array}{l}\bullet 18-<45 \\
\bullet \geq 45\end{array}$ & $\begin{array}{c}326(81.5) \\
74(18.5)\end{array}$ & $\begin{array}{c}126(74.1) \\
44(25.9)\end{array}$ & $\begin{array}{l}200(87.0) \\
30(13.0)\end{array}$ & $10.687(.001)^{*}$ \\
\hline BMI & $\begin{array}{l}\text { - Underweight } \\
\text { - Normal } \\
\text { - Obese } \\
\text { - Overweight }\end{array}$ & $\begin{array}{c}14(3.5) \\
156(39) \\
147(36.8) \\
83(20.8) \\
\end{array}$ & $\begin{array}{c}4(2.4) \\
70(41.2) \\
72(42.4) \\
24(14.1) \\
\end{array}$ & $\begin{array}{c}10(4.3) \\
86(37.4) \\
75(32.6) \\
59(25.7) \\
\end{array}$ & $10.264(.015) *$ \\
\hline Marital status & $\begin{array}{l}\text { - Single } \\
\text { - Married } \\
\text { - Divorced } \\
\text { - Widow }\end{array}$ & $\begin{array}{c}123(30.8) \\
251(62.7) \\
20(5.0) \\
6(1.5) \\
\end{array}$ & $\begin{array}{c}40(23.5) \\
124(72.9) \\
4(2.4) \\
2(1.2) \\
\end{array}$ & $\begin{array}{c}83(36.1) \\
127(55.2) \\
16(7.0) \\
4(1.7) \\
\end{array}$ & $14.256(.002) *$ \\
\hline Nationality & $\begin{array}{l}\text { - Saudi } \\
\text { - Non- Saudi }\end{array}$ & $\begin{array}{c}304(76) \\
96(24)\end{array}$ & $\begin{array}{r}124(72.9) \\
46(27.1) \\
\end{array}$ & $\begin{array}{l}180(78.3) \\
50(21.7) \\
\end{array}$ & $1.517(.237)$ \\
\hline Educational Level & $\begin{array}{l}\text { - Primary school } \\
\text { - Secondary school } \\
\text { - College }\end{array}$ & $\begin{array}{c}22(5.5) \\
19047.5) \\
188(47) \\
\end{array}$ & $\begin{array}{c}5(2.9) \\
85(50.0) \\
80(47.1)\end{array}$ & $\begin{array}{c}17(7.4) \\
105(45.7) \\
108(47.0) \\
\end{array}$ & $3.909(.145)$ \\
\hline Monthly income & $\begin{array}{l}\text { - Low } \\
\text { - Average } \\
\text { - High } \\
\end{array}$ & $\begin{array}{c}218(45.5) \\
108(27) \\
74(18.5) \\
\end{array}$ & $\begin{array}{l}64(37.6) \\
57(33.5) \\
49(28.8) \\
\end{array}$ & $\begin{array}{l}154(67.0) \\
51(22.2) \\
25(10.9) \\
\end{array}$ & $37.108(.000) *$ \\
\hline Current Smoking & $\begin{array}{l}\bullet \text { No } \\
\bullet \text { Yes }\end{array}$ & $\begin{array}{l}308(77) \\
92(23)\end{array}$ & $\begin{array}{l}91(53.5) \\
79(46.5)\end{array}$ & $\begin{array}{l}217(94.3) \\
13(5.7)\end{array}$ & $91.962(.000)^{*}$ \\
\hline $\begin{array}{l}\text { Having a family history of } \\
\text { cardiovascular diseases }\end{array}$ & $\begin{array}{l}\bullet \text { No } \\
\bullet \text { Yes }\end{array}$ & $\begin{array}{l}229(57.3) \\
171(42.8)\end{array}$ & $\begin{array}{l}103(60.6) \\
673(9.40\end{array}$ & $\begin{array}{l}126(54.8) \\
104(45.2)\end{array}$ & $1.346(.262)$ \\
\hline $\begin{array}{l}\text { Having chronic medical } \\
\text { conditions. }\end{array}$ & $\begin{array}{l}\bullet \text { No } \\
\bullet \text { Yes }\end{array}$ & $\begin{array}{c}317(79.3) \\
83(20.8) \\
\end{array}$ & $\begin{array}{c}134(78.8) \\
36(21.2)\end{array}$ & $\begin{array}{l}183(79.6) \\
47(20.4) \\
\end{array}$ & $.033(.901)$ \\
\hline Perceived stress & \begin{tabular}{|l|} 
No \\
- Yes \\
\end{tabular} & $\begin{array}{c}73(18.3) \\
327(81.8) \\
\end{array}$ & $\begin{array}{c}42(24.7) \\
128(75.3) \\
\end{array}$ & $\begin{array}{r}31(13.5) \\
199(86.5) \\
\end{array}$ & $8.259(.006) *$ \\
\hline Practicing exercise & $\begin{array}{l}\bullet<3 \text { times/week } \\
\bullet \geq 3 \text { times/week }\end{array}$ & $\begin{array}{c}313(78.3) \\
87(21.8) \\
\end{array}$ & $\begin{array}{c}130(76.5) \\
40(23.5) \\
\end{array}$ & $\begin{array}{c}183(79.6) \\
47(20.4) \\
\end{array}$ & $.550(.465)$ \\
\hline
\end{tabular}

* Statistically significant differences 
Table (2): Cardiovascular diseases preventive measures as mention by the study sample, $n=400$

\begin{tabular}{|c|c|c|c|c|c|}
\hline \multirow[t]{2}{*}{ List of preventive measures } & $\begin{array}{l}\text { Strongly } \\
\text { agree }\end{array}$ & Agree & $\begin{array}{l}\text { Do not } \\
\text { know }\end{array}$ & Disagree & $\begin{array}{l}\text { Strongly } \\
\text { disagree }\end{array}$ \\
\hline & \multicolumn{5}{|c|}{$\mathbf{N}(\%)$} \\
\hline 1. Smoking cessation & $248(62.0)$ & 91(22.8) & $27(6.8)$ & $26(6.5)$ & $8(2)$ \\
\hline $\begin{array}{l}\text { 2. Control obesity by exercise and appropriate } \\
\text { diet. }\end{array}$ & 277(69.3) & $115(28.7)$ & $4(1.0)$ & $3(0.8)$ & $1(0.3)$ \\
\hline 3. Maximum 5 hours of sleep each night. & 197(49.3) & 131(32.8) & $25(6.3)$ & $40(10)$ & $7(1.8)$ \\
\hline 4. Compliance with blood pressure medication. & $112(28)$ & 102(25.5) & $147(36.8)$ & $31(7.8)$ & $8(2.0)$ \\
\hline 5. Compliance with cholesterol medication. & 119(29.8) & 132(33) & $126(31.5)$ & $18(4.5)$ & $5(1.3)$ \\
\hline 6. Regular health screening. & 251(62.7) & 117(29.3) & $25(6.3)$ & $6(1.5)$ & $1(0.3)$ \\
\hline 7. Exercise $30 \mathrm{~min} / 3$ times/week. & 171(42.8) & 149(37.3) & $61(15.3)$ & $16(4)$ & $3(0.8)$ \\
\hline 8. Practicing relaxation techniques. & 119(29.8) & 183(45.8) & $86(21.5)$ & $11(2.8)$ & $1(0.3)$ \\
\hline 9. Regular monitoring of blood glucose. & 150(37.5) & $161(40.3)$ & $79(19.8)$ & $9(2.3)$ & $1(0.3)$ \\
\hline $\begin{array}{l}\text { Mean } \pm \text { SD: } \\
\text { Range: }\end{array}$ & \multicolumn{5}{|c|}{$\begin{array}{l}38.00 \pm 4.001(\text { Median }=38.00) \\
22-45\end{array}$} \\
\hline
\end{tabular}

Table (3): Awareness of the warning symptoms of a heart attack, $n=400$

\begin{tabular}{|c|c|c|c|c|c|}
\hline \multirow{3}{*}{ Symptoms } & \multicolumn{2}{|c|}{$\begin{array}{c}\text { Entire sample, } n=400 \\
N(\%)\end{array}$} & \multicolumn{3}{|c|}{$\begin{array}{c}\text { Comparison between males and females } \\
\mathrm{N}(\%) \text { of yes responses } \\
\end{array}$} \\
\hline & \multirow[t]{2}{*}{ No } & \multirow[t]{2}{*}{ Yes } & $\begin{array}{c}\text { Male } \\
(\mathbf{N}=169)\end{array}$ & $\begin{array}{l}\text { Female } \\
(\mathbf{N}=230)\end{array}$ & \multirow{2}{*}{$\begin{array}{c}\text { Chi-square } \\
\text { (P-value) }\end{array}$} \\
\hline & & & \multicolumn{2}{|c|}{$\mathbf{N}(\%)$} & \\
\hline 1. Chest pain & $131(32.8)$ & $269(67.3)$ & $101(59.4)$ & $168(73.0)$ & $8.247(.005) *$ \\
\hline 2. Shortness of breath & $107(26.8)$ & $293(73.3)$ & $120(70.6)$ & $173(75.2)$ & $1.069(.306)$ \\
\hline 3. Sweatiness & $168(42)$ & $232(58)$ & $94(55.3)$ & $138(60.0)$ & $.889(.358)$ \\
\hline 4. Weakness or fatigue & $110(27.5)$ & $290(72.5)$ & $108(63.5)$ & $182(79.1)$ & $11.933(.001) *$ \\
\hline 5. Jaw and neck pain & $283(70.8)$ & $117(29.3)$ & $51(30.0)$ & $66(28.7)$ & $.080(.824)$ \\
\hline 6. Palpitations $(n=399) *$ & $111(27.8)$ & $288(72)$ & $113(66.5)$ & $175(76.1)$ & $4.127(.057)$ \\
\hline
\end{tabular}

* Statistically significant differences

Table (4): Factors associated with awareness of symptoms and awareness of preventive measures, $\mathrm{n}=\mathbf{4 0 0}$

\begin{tabular}{|c|c|c|c|c|c|}
\hline \multirow[t]{2}{*}{ Demographic data } & \multirow[t]{2}{*}{$\mathbf{N}(\%)$} & $\begin{array}{c}\text { Awareness of } \\
\text { symptoms }\end{array}$ & \multirow[t]{2}{*}{$\begin{array}{c}\text { F/T } \\
\text { (p-value) }\end{array}$} & \multirow{2}{*}{$\begin{array}{c}\begin{array}{c}\text { Awareness of } \\
\text { preventive } \\
\text { measures }\end{array} \\
\text { Mean } \pm \text { SD } \\
\end{array}$} & \multirow[t]{2}{*}{ F/T(p-value) } \\
\hline & & Mean \pm SD & & & \\
\hline $\begin{array}{l}\text { Age } \\
\text { - } 18-<45 \\
\text { - } \geq 45\end{array}$ & $\begin{array}{c}326(81.5) \\
74(18.5)\end{array}$ & $\begin{array}{l}4.22 \pm 2.118 \\
4.53 \pm 1.676\end{array}$ & $-1.195(.233)$ & $\begin{array}{l}37.47 \pm 3.703 \\
38.16 \pm 5.104\end{array}$ & $-1.346(.179)$ \\
\hline $\begin{array}{l}\text { BMI } \\
\text { - Underweight } \\
\text { - Normal } \\
\text { - Obese } \\
\text { - Overweight }\end{array}$ & $\begin{array}{c}14(3.5) \\
156(39) \\
147(36.8) \\
83(20.8)\end{array}$ & $\begin{array}{l}3.36 \pm 1.985 \\
4.09 \pm 2.162 \\
4.21 \pm 1.963 \\
4.90 \pm 1.850\end{array}$ & $10.276(.001)^{*}$ & $\begin{array}{l}35.64 \pm 3.079 \\
37.38 \pm 3.634 \\
37.71 \pm 4.113 \\
38.13 \pm 4.501\end{array}$ & 4.084(.044) * \\
\hline $\begin{array}{l}\text { Gender } \\
\text { - Male } \\
\text { - Female }\end{array}$ & $\begin{array}{l}170(42.5) \\
230(57.5)\end{array}$ & $\begin{array}{l}3.99 \pm 2.087 \\
4.49 \pm 1.993\end{array}$ & $-2.421(.016) *$ & $\begin{array}{l}37.29 \pm 4.173 \\
37.83 \pm 3.863\end{array}$ & $-1.330(.184)$ \\
\hline $\begin{array}{l}\text { Marital status } \\
\text { - Single } \\
\text { - Married } \\
\text { - Divorced } \\
\text { - Widow }\end{array}$ & $\begin{array}{c}123(30.8) \\
251(62.7) \\
20(5.0) \\
6(1.5)\end{array}$ & $\begin{array}{l}4.07 \pm 2.093 \\
4.29 \pm 2.061 \\
5.00 \pm 1.487 \\
5.50 \pm 1.225\end{array}$ & $4.815(.029) *$ & $\begin{array}{l}36.69 \pm 3.518 \\
38.04 \pm 4.186 \\
38.45 \pm 3.316 \\
34.83 \pm 3.920\end{array}$ & $3.985(.047) *$ \\
\hline $\begin{array}{l}\text { Nationality } \\
\text { - Saudi } \\
\text { - Non- Saudi }\end{array}$ & $\begin{array}{c}304(76) \\
96(24)\end{array}$ & $\begin{array}{l}4.18 \pm 2.147 \\
4.58 \pm 1.659\end{array}$ & $-1.695(.091)$ & $\begin{array}{l}37.60 \pm 4.064 \\
37.60 \pm 3.815\end{array}$ & $-.019(.985)$ \\
\hline
\end{tabular}




\begin{tabular}{|c|c|c|c|c|c|}
\hline \multirow[t]{2}{*}{ Demographic data } & \multirow[t]{2}{*}{$\mathbf{N}(\%)$} & $\begin{array}{l}\text { Awareness of } \\
\text { symptoms }\end{array}$ & \multirow[t]{2}{*}{$\underset{\text { (p-value) }}{\mathbf{F} / \mathbf{T}}$} & $\begin{array}{c}\text { Awareness of } \\
\text { preventive } \\
\text { measures }\end{array}$ & \multirow[t]{2}{*}{ F/T(p-value) } \\
\hline & & Mean \pm SD & & Mean \pm SD & \\
\hline $\begin{array}{l}\text { Educational Level } \\
\text { - Primary school } \\
\text { - Secondary } \\
\text { school } \\
\text { - College }\end{array}$ & $\begin{array}{c}22(5.5) \\
19047.5) \\
188(47)\end{array}$ & $\begin{array}{l}4.09 \pm 2.136 \\
4.15 \pm 2.000 \\
4.43 \pm 2.081\end{array}$ & $1.761(.185)$ & $\begin{array}{l}39.23 \pm 4.208 \\
37.25 \pm 4.282 \\
37.76 \pm 3.630\end{array}$ & $.017(.896)$ \\
\hline $\begin{array}{l}\text { Monthly income } \\
\text { - Low } \\
\text { - Average } \\
\text { - High }\end{array}$ & $\begin{array}{c}218(45.5) \\
108(27) \\
74(18.5)\end{array}$ & $\begin{array}{l}4.20 \pm 1.991 \\
4.31 \pm 2.177 \\
4.47 \pm 2.021\end{array}$ & $.960(.328)$ & $\begin{array}{l}37.41 \pm 4.009 \\
38.03 \pm 4.061 \\
37.51 \pm 3.897\end{array}$ & $.301(.583)$ \\
\hline $\begin{array}{l}\text { Current Smoking } \\
\bullet \quad \text { No } \\
-\quad \text { Yes }\end{array}$ & $\begin{array}{c}308(77) \\
92(23)\end{array}$ & $\begin{array}{l}4.24 \pm 2.100 \\
4.40 \pm 1.858\end{array}$ & $-.676(.500)$ & $\begin{array}{l}37.99 \pm 3.835 \\
36.27 \pm 4.274\end{array}$ & 3.678(.000) $*$ \\
\hline $\begin{array}{l}\text { Having a family } \\
\text { history } \\
\text { cardiovascular } \\
\text { diseases } \\
\text { - No } \\
\text { - Yes }\end{array}$ & $\begin{array}{l}229(57.3) \\
171(42.8)\end{array}$ & $\begin{array}{l}3.96 \pm 2.097 \\
4.70 \pm 1.901\end{array}$ & $-3.607(.000) *$ & $\begin{array}{l}37.57 \pm 3.873 \\
37.64 \pm 4.178\end{array}$ & $-.172(.863)$ \\
\hline $\begin{array}{l}\text { Having chronic } \\
\text { medical } \\
\text { conditions } \\
\text { - No } \\
\text { - Yes }\end{array}$ & $\begin{array}{c}317(79.3) \\
83(20.8)\end{array}$ & $\begin{array}{l}4.16 \pm 2.143 \\
4.71 \pm 1.551\end{array}$ & $-2.153(.032) *$ & $\begin{array}{l}37.53 \pm 3.758 \\
37.86 \pm 4.837\end{array}$ & $-.659(.510)$ \\
\hline $\begin{array}{l}\text { Perceived stress } \\
\text { • No } \\
\text { - Yes }\end{array}$ & $\begin{array}{c}73(18.3) \\
327(81.8)\end{array}$ & $\begin{array}{l}3.45 \pm 2.334 \\
4.46 \pm 1.932\end{array}$ & $-3.872(.000) *$ & $\begin{array}{l}37.58 \pm 3.880 \\
37.60 \pm 4.034\end{array}$ & $-.052(.958)$ \\
\hline $\begin{array}{l}\text { Practicing } \\
\text { exercise } \\
0<3 \text { times/week } \\
\text { - } \geq 3 \text { times/week }\end{array}$ & $\begin{array}{c}313(78.3) \\
87(21.8)\end{array}$ & $\begin{array}{l}4.18 \pm 2.045 \\
4.61 \pm 2.025\end{array}$ & $-1.724(.086)$ & $\begin{array}{l}37.60 \pm 3.937 \\
37.57 \pm 4.250\end{array}$ & $.060(.952)$ \\
\hline
\end{tabular}

* Statistically significant differences

Table (1): Sociodemographic characteristics of the entire sample Displays the characteristics of the respondents $(n=400)$. The mean age of the respondents was $34.40 \pm 1.28$; the majority $(81.5 \%)$ had an age range between 18-45 years. Most of the respondents were Saudi nationals $(76.0 \%)$, females $(57.5 \%)$, and married $(62.8 \%)$. Less than half $(47.0 \%)$ had a university education. More than half $(57.6 \%)$ were either overweight or obese. A few were smokers (23\%) and had a chronic medical condition (20.8\%). Statistically significant differences were found between males and females related to their age-BMI, marital status, income, current smoking, and perceived stress.

Table (2): Awareness of CVDs risks preventive measures Shows the awareness of CVDs preventive measures among the respondents. The majority of them (strongly) agreed that smoking cessation $(84.8 \%)$, active exercises $(80.1 \%)$, and control of obesity through an appropriate diet $(98 \%)$ could prevent CVDs. Around two-thirds (77.8\%) also (strongly) agreed that regular blood glucose monitoring could prevent CVDs. However, most of the respondents (strongly) agreed that taking blood pressure $(53.5 \%)$ and cholesterol medication (62.8\%) can prevent CVDs. Men and women had the same level of awareness about preventive measures for CVDs.

Table (3):Awareness of heart attack warning symptoms:Shows the awareness of the heart attack warning symptoms among the respondents. Looking at each symptom, most of the respondents recognized shortness of breath $(73.3 \%)$ and weakness or fatigue $(72.5 \%)$ as warning symptoms, followed by chest pain $(67.3 \%)$. Only a low number $(27.3 \%)$ recognized jaw and neck pain as symptoms of a heart attack. Females had a higher awareness level than males about symptoms of chest pain (chi-square $=8.247$, at $\mathrm{p}=.005$ ) and weakness or fatigue (chi-square $=$ 
11.933, at $\mathrm{p}=.001$ ), but their awareness level regarding other symptoms was similar.

Table (4): Factors determine the awareness about heart attack warning symptoms and CVDs preventive measures .Illustrated the association between sociodemographic data and an overall score of (i) awareness of symptoms and (ii) awareness of preventive measures. Results revealed that those who were overweight, female, widow, having a family history of CVD, having a chronic health condition, and reporting having stress were more likely to have a higher awareness level of heart attack symptoms $(\mathrm{p}<0.05)$ than others. Also, respondents who were overweight, divorced, and nonsmokers were more likely to have a high level of awareness of CVDs preventive measures $(\mathrm{p}<0.05)$.

\section{Discussion}

This comparative cross-sectional survey was done among 400 adults (170 men and 230 women) in Riyadh to evaluate the types and prevalence of CVDs risks and awareness of preventive measures and compare the awareness of heart attack warning symptoms among males and females.

The prevalence of CVDs risk factors was high among our study respondents, especially females, where the majority had at least one of the most common CVDs risk factors. For instance, most of them had a family history of CVDs, were obese and physically inactive, and a few were smokers and had chronic conditions like diabetes, hypertension, and hypercholesterolemia. Our findings are in line with previous studies' findings, which show that the prevalence of CVDs risk factors is noticeably high among Saudi mainly due to obesity and sedentary lifestyle (Alshaikh et al., 2016; Mujamammi et al., 2020), which considerably increases women's susceptibility for CVDs.

In Saudi Arabia, obesity is highly prevalent and might increase in the future. $59.5 \%$ of the population may suffer from obesity in Saudi Arabia by 2022 (Alqarni, 2016). Between 1980 \& 2015, the body mass index increased by nearly $11.6 \%$ in women and $13.1 \%$ in men globally (Manrique-Acevedo et al., 2020). Obesity-related comorbidities are increasing globally. Obesity constitutes one of the most critical risk factors for chronic diseases such as diabetes mellitus, hypertension, fatty liver disease, stroke, and other NCDs, thereby contributing to poor quality of life and a decrease in life expectancy (Blüher, 2019; Manrique-Acevedo et al., 2020). A sedentary lifestyle and a poor diet seem to be the main drivers of the obesity pandemic. On the other hand, Abdo Ahmed et al. (2020), in their study that assessed the awareness of the risk factors for heart attack among the general public in Pahang, Malaysia, reported that diabetes $(26 \%)$ was the risk factor that their study's respondents least recognized.

Regarding the awareness of CVDs preventive measures, the current study found that most respondents strongly agreed that smoking cessation, active exercises, and control of obesity through an appropriate diet could prevent CVDs. In the same line, Abdo Ahmed et al. (2020) reported that the majority of the respondents identified smoking and obesity as risk factors for heart attack and also the multivariable logistic regression showed that respondents with a family history of heart attack had an excellent level of awareness.

Our study key findings showed that women were more likely to have a higher level of perceived stress than men. Gender has been an important biological determinant of vulnerability to stress (Alshammari et al., (2020), making women highly susceptible to CVDs. Nowadays, raising awareness of the population about the symptoms of stress and how to overcome them has become essential, as it helps prevent many of the diseases associated with it.

This study showed that more than a quarter of the respondents did not know CVDs risk factors and their preventive measures. Previous studies in Riyadh found that more than a third of the respondents did not know that an unhealthy diet, smoking, dyslipidemia, physical inactivity (Mujamammi et al., 2020), and uncontrolled hypertension (Alotaibi et al., 2018) are risks for CVDs.

The knowledge of CVDs risks and warning symptoms of heart attacks among the respondents were suboptimal. The majority of our respondents did not recognize the critical warning symptoms of a heart attack. However, the majority could identify shortness of breath, and weakness or fatigue as warning symptoms, followed by chest pain. Conversely, a few of the respondents recognized the most common heart attack symptoms (i.e., jaw and neck pain). Similarly, respondents in previous studies in Riyadh (Mujamammi et al., 2020) and Cameron (Aminde et al., 2017) reported shortness of breath as a heart attack warning symptom. Other significant symptoms, such as pain in the left arm or shoulder, pain in the jaw, weakness, or light-headedness, were identified only by a minority of the respondents, similar to a previous study (Aminde et al., 2017). In Kuwait, two-fifths of the respondents $(n=900)$ were not aware of any heart attack symptoms, while almost half of the respondents reported chest pain and shortness of breath (Awad \& Al-Nafisi, 2014). These results indicate that further attention must be directed 
towards enhancing the population's understanding of significant heart attack symptoms.

Our findings are congruent with previous studies' findings, where females had a better knowledge of the warning symptoms of heart attacks and strokes than males (Aminde et al., 2017; Awad \& Al-Nafisi, 2014). Females had a higher awareness level than males about the key symptoms, such as chest pain, weakness, and fatigue, their awareness of other symptoms was almost the same. These findings might be because women have a higher self-awareness of their health. It could also be that they are more likely to attend heart health campaigns which include different awareness strategies regarding many common health problems. On the other hand, KoniakGriffin and Brecht (2015), in their study to assess the awareness of CVDs and preventive behaviours among overweight immigrant Latinas, reported that many women possessed limited knowledge about heart disease and prevention strategies.

\section{Conclusion :}

Our study is among the first to compare awareness of CVD risk in men versus women. Lack of knowledge of CVD risks, and preventive measures, and heart attack warning symptoms is suboptimal. Obesity and stress are widespread among women. Nevertheless, women were more aware of heart attack warning symptoms than men. Subsequently,

\section{Recommendations:}

we recommend that:

- Healthcare policymakers, public health workers, and professional cardiovascular nurses develop a comprehensive, evidence-based public health education program that taking into consideration gender differences.

- Ministry of health can facilitate electronic services of sending cell phone messages to provide cardiac health tips and describe the warning symptoms of heart attacks while considering the population's literacy level.

- The population's awareness is the responsibility of every healthcare professional member, especially community and medical-surgical nurses. Thus, heart health screening and awareness campaigns can be arranged at regular intervals in the outpatient setting during the patients' and their relatives' waiting time and for patients' visitors to the hospital.

- Nurses should provide ongoing training to inform people about CVDs risks and prevention by promoting healthy heart habits. Also, future research to deeply explore stress and its predictors and develop evidence-based stress control programs among Saudi women is needed.
- Nurses have a significant responsibility to design evidence-based health education programs to reinforce the population's positive attitude towards adopting a healthy lifestyle and recognizing risks of CVDs.

\section{Limitations}

Although the cross-section design was used in this study, an adequately computed sample was recruited from several geographical regions in the capital of Saudi Arabia, which increases the possibility of generalizing the results to other sites. Also, establishing a causal relationship between the examined variables was impossible because the adopted design was a snapshot. Thus, future studies using other methods may yield different results.

Acknowledgements

The authors would like to express their gratitude to all the respondents for giving us their time to participate in this survey.

Contribution

SSS \& HAG: Conceptualized and designed the study. NY: Analyzed the data, interpreted the findings. SSS \& NY: write the manuscript. FA, WA, \& HA collected the study data. All authors have made substantive contributions to the study and approved the final draft.

\section{Conflict of interest}

The authors declare that there is no conflict of interest.

\section{References}

- Abdo Ahmed A.A., AL-Shami A.M, JamshedS, Zawiah M. Elnaem MH, \& Ibrahim M. (2020): Awareness of the Risk Factors for Heart Attack Among the General Public in Pahang, Malaysia: A Cross-Sectional Study. Risk Management and Healthcare Policy journal 2020:13 3089-3102 available at: https://www.dovepress.com/getfile.php?fileID=651 $\underline{25}$

- Alotaibi, A., Albahlal, A., Alotaibi, F., Alkurdi, F., Atef, M., Almuhraj, M., Alenazi, T. (2018): General public awareness about symptoms and risk factors of some cardiovascular diseases in KSA, Riyadh 2017. IJSER, 9, 603.

- Alqarni, S. (2016): A review of prevalence of obesity in Saudi Arabia. J Obes Eat Disord, 2(2), 16.

- Alshammari, Y., Alharthy, M., \& Alanazi, F. (2020): Awareness and prevalence of coronary artery disease risk factors among Saudi adults in Dawadmi, Riyadh province: A cross-sectional study. Journal of Family Medicine and Primary Care, 9(11), 5629. 
- Alshaikh, M., Filippidis, F., Baldove, J., Majeed, A., \& Rawaf, S. (2016): Women in Saudi Arabia and the prevalence of cardiovascular risk factors: A systematic review. Journal of Environmental and Public Health, 2016. https://doi.org/10.1155/2016/7479357

- Aminde, L., Takah, N., Ngwasiri, C., Noubiap, J., Tindong, M., Dzudie, A., \& Veerman, J. (2017): Population awareness of cardiovascular disease and its risk factors in Buea, Cameroon. BMC Public Health, 17(1), 1-10. https://doi.org/10.1186/s12889-017-4477-3

- Awad, A., \& Al-Nafisi, H. (2014): Public knowledge of cardiovascular disease and its risk factors in Kuwait: A cross-sectional survey. BMC Public Health, 14(1), 1-11. https://doi.org/10.1186/1471-2458-14-1131

- Benjamin, E., Muntner, P., Alonso, A., Bittencourt, M., Callaway, C., Carson, A., Das, S. (2019). Heart disease and stroke statistics - 2019 update: A report from the American heart association. Circulation, 139(10), e56-e528. https://doi.org/10.1161/CIR.0000000000000659

- Benjamin, E., Virani, S., Callaway, C., Chamberlain, A., Chang, A., Cheng, S., (2018): American Heart Association Council on Epidemiology and Prevention Statistics Committee and Stroke Statistics Subcommittee. (2018). Heart disease and stroke statistics-2018 update: A report from the American heart association. Circulation, 137(12), e67-e492. doi:10.1161/CIR.0000000000000558 [doi]

- Blüher, M. (2019): Obesity: Global epidemiology and pathogenesis. NatureReviews Endocrinology, 15(5), 288-298. https://doi.org/10.1038/s41574-019-0176-8

- Centers for Disease Control and Prevention (CDC). Global Health - Saudi Arabia, (2018): last reviewed: October 23, 2019. Retrieved April 20 ,

2021,

from https://www.cdc.gov/globalhealth/countries/sa udi_arabia/pdf/Saudia-arabia Factsheet.pdf,

- Coke, L., \& Hayman, L. (2021): Women's awareness of heart disease and risk: Two steps forward and one-step back. Journal of Cardiovascular Nursing, 36(1), 6-7. DOI: 10.1097/JCN.0000000000000772

- Gagnon, I. (2021): Economic burden of CVD in Saudi Arabia to jump to $\$ 9.8$ bn by 2035 . Retrieved February 20, 2021 from https://saudigazette.com.sa/article/530006/BUSINE SS/Economic-burden-of-CVD-in-Saudi-Arabia-tojump-to-\$98bn-by-
2035. WWW.Saudigazette.Com.Sa - All Rights Reserved

- Gao, Z., Chen, Z., Sun, A., \& Deng, X. (2019): Gender differences in cardiovascular disease. Medicine in Novel Technology and Devices, 4, 100025. https://doi.org/10.1016/j.medntd.2019.100025

- Koniak-Griffin D., Brecht M. (2015): Awareness of Cardiovascular Disease and Preventive Behaviors among Overweight Immigrant Latinas. Journal of Cardiovascular Nursing. . 2015 Sep-Oct; 30(5): 447-455. doi: 10.1097/JCN.0000000000000181. Available at: https://www.ncbi.nlm.nih.gov/pmc/articles/PMC43 $12257 /$

- Manrique-Acevedo, C., Chinnakotla, B., Padilla, J., Martinez-Lemus, L., \& Gozal, D. (2020): Obesity and cardiovascular disease in women. International Journal of Obesity, 44(6), 1210-1226.

https://link.springer.com/content/pdf/10.1007/s1188 3-002-0049-8.pdf

- Mujamammi, A., Alluhaymid, Y., Alshibani, M., Alotaibi, F., Alzahrani, K., Alotaibi, A., \& Sabi, E. (2020): Awareness of cardiovascular disease associated risk factors among Saudis in Riyadh city. Journal of Family Medicine and Primary Care, 9(6), $3100 . \quad$ DOI: 10.4103/jfmpc.jfmpc_458_20

- Saudi Ministry of Health. (2013): Cardiovascular diseases cause $42 \%$ of non-communicable diseases deaths in the kingdom. Retrieved December 20, 2020.

from https://www.moh.gov.sa/en/Ministry/MediaCe nter/News/Pages/News-2013-10-30-002.aspx,

- Virani, S., Alonso, Benjamin, E., Bittencourt, M., Callaway, C., Carson, A., \& Delling, F. (2020): Heart disease and stroke statistics-2020 update: A report from the American heart association. Circulation, 141(9), e139-e596. https://doi.org/10.1161/CIR.0000000000000757

- World Health Organization. (2017): Cardiovascular diseases (CVDs) Retrieved January 26, 2021, from https://www.who.int/news-room/fact sheets/detail/cardiovascular-diseases-(cvds).

- Zhou, Q., \& Bei, Y. (2020): Gender differences in cardiovascular diseases. Gender Differences in Cardiovascular Diseases, 13, 1-2. doi: https://doi.org/10.1007/s12265-020-09956-9. 